\title{
Scale as an 'Active Progenitor' in the Metamorphosis of the Waste Management Hierarchy in Member States: The Case of the Republic of Ireland
}

\section{MARK BOYLE}

\begin{abstract}
In the light of the raft of legislation introduced by the European Commission since the late 1980s, waste management planning in the European Union (EU) is currently undergoing tumultuous restructuring. At the heart of this restructuring is the requirement by member states to formulate waste management plans that embrace the Commission's central concept of the waste management hierarchy. This article begins with the assertion that the grounding of the waste management hierarchy in different European countries reflects members' ongoing difficulties balancing supra-national environmental regulations with the imperatives of national accumulation strategies. Central to negotiating this tightrope has been a tremendous transformation, modification, re-jigging and re-calibration of the hierarchies of waste management planning institutions in member states. The core argument advanced in this article is that far from being a neutral or technical or practical side show, contemporary (re)scalings of waste management planning in Europe must be approached as being centrally implicated in the constitution of forms of environmental controls that serve rather than burden the interests of leading capitals. This argument is illustrated through a detailed case study of recent scalar inventions in waste management planning in the Republic of Ireland.
\end{abstract}

\section{Introduction}

Alongside the concepts of 'competitiveness' and 'cohesion', environmental 'sustainability' stands as one of the European Commission's (EC's) foundational tenets, and in the light of recent trends in the economy, waste management has surfaced as one of its most active areas of environmental regulation (European Environment Agency, 2000; European Commission, 2001). Against the backdrop of the raft of legislation introduced by the Commission since the late 1980s, waste management planning in the European Union (EU) at present is character-

Mark Boyle, Department of Geography, University of Strathclyde, Graham Hills Building, 50 Richmond Street, Glasgow G1 1XN, UK. E-mail: mark.boyle@strath.ac.uk 
ized by tumultuous restructuring. At the heart of this restructuring is the requirement by member states to formulate waste management plans that embrace the Commission's central concept of the waste management hierarchy.

This article is concerned with the theoretical tools available to researchers interested in exploring the different ways in which the concept of the waste management hierarchy is grounding itself in different member states. It begins with the observation that the transposition of the concept into practice must be seen as a highly politically charged exercise, reflecting members' ongoing struggles to juggle EC imposed environmental regulations whilst at the same time defending and indeed prioritizing national accumulation strategies. The different strategies employed by member states whilst walking this tightrope have resulted in the waste management hierarchy resurfacing in a multiplicity of guises in emerging waste management plans. Mapping and explaining the metamorphosis of this principle as it becomes reworked in different European states then, is emerging as an important area for research.

This article notes that in attempting to reconcile economic objectives with environmental obligations, national governments have embarked upon a tremendous transformation, modification, re-jigging, and re-calibration of the hierarchies of waste management planning institutions in member states. All over Europe, old waste management planning areas are being dusted down and looked at afresh, dismantled, bolstered, synthesized, fragmented, and reconfigured as part and parcel of the new regimes of waste management planning (Davoudi, 2000; Wilson et al., 2001). The core argument advanced in this article is that by choosing to 'scale' waste management planning in certain ways, national governments are, to a fundamental extent, already conditioning the kinds of engagements with the waste management hierarchy that are open to planners. That scale is an active force in determining approaches to waste management planning, it follows that different scalar strategies open up different levels of threat/opportunities to national economic development priorities. This article contends that far from being a neutral or technical or practical side show, contemporary (re)scalings of waste management planning in Europe must be approached as being, to quote Neil Smith (1993, p. 101), an 'active progenitor' in the constitution of forms of environmental controls that serve rather than burden the interests of leading capitals (see also Boyle, 2002).

The analysis offered here has parallels with recent literature which has sought to theorize the emergence of multi-level governance in Europe and in particular the rise of a 'Europe of the Regions' (Hooghe, 1996; Baeten et al., 1999; Brenner, 1999; MacLeod, 1999; Boyle, 2000). Approaching 'scale' as a resource employed by the most economically powerful groups, this research has sought to relate struggles over new scale divisions of state authority in Europe to prevailing patterns of political economy (focussing upon uneven development, class relations, wealth redistribution and so on). Whilst this article is fuelled by the same theoretical interests - scale as a social process rather than a reified entity - attention has been given not to how particular scalar 'fixes' allow hegemonic forces to control and exploit other 'class' groups, but instead how scale is used as a resource to facilitate control by dominant forces over 'nature'. Whilst the scalar processes that are currently reconfiguring the apparatus of governance in the EU at present need to be rooted in prevailing political economies to be properly understood, this article contends that existing literature on 'multi-level governance' might be extended if researchers also locate scalar processes inside prevailing political ecologies.

A central feature of literature which attempts to theorize scale in terms of class conflict over the division of the (inter)national product is the emphasis which is placed on struggles over scale (Swyngedouw, 1997, 2000; Cox, 1998; Brenner, 1998; 2001; MacLeod \& Goodwin, 1999). Whilst the starting point might attribute capital with the ultimate authority over the 'fixing' of scale, the institutions that are therein secreted are always open to contestation and 
their reproduction is always contingent and contextual. The notion of the scalar dialectic captures this well, drawing attention to the ways in which scalar scaffolds not only serve elite groups but also contain within themselves the seeds of their own downfall. Scale serves as an active progenitor of both hegemonic dominance and new forms of resistance; it both functions and malfunctions, fixes but unravels, and constitutes whilst introducing new threats to the interests of elite groups. The notion of a scalar dialectic producing an ongoing process of structuration in the forms and substance of planning provides a useful conceptual frame for the present study.

In an effort to demonstrate the importance of the scalar constitution of waste management planning in the reworking of the principle of the waste management hierarchy into practice, this article presents a case study of waste management planning in the so-called Celtic Tiger - the Republic of Ireland. What to do with the increasing amounts of waste generated by a rapidly growing economy is emerging as one of Ireland's most important and politically controversial environmental issues (Environmental Protection Agency, 2000a; OECD, 2000; Clinch et al., 2002). Caught between the devil of supporting a highly successful export oriented accumulation strategy predicated upon embedding leading US transnationals and globalizing local firms (O'Hearn, 2000; O'Rain, 2000), and the deep blue sea of demonstrating to the EC a commitment to implementing the waste management hierarchy, the Irish State has actively sought to 'invent' a new regional scale for waste management planning. Ireland's 'fixing' of waste management planning at the regional level and the struggles which have surrounded the formulation and implementation of regional plans, serves as an excellent window into the utility of the concept of the scalar dialectic in this context.

The remainder of the article is organized around five sections. First, focusing upon the principle of the waste management hierarchy, the EC's approach to waste management planning will be introduced. Second, the nature of Ireland's waste management problems will be outlined. Third, the policy initiatives the Irish government has pursued to address these problems will be reviewed. Fourth, the constitutive importance of Ireland's decision to regionalize waste management planning will be discussed. Here the ways in which 'scale' functions as an active progenitor of both hegemonic dominance and ecological resistance will be outlined. Finally, the somewhat draconian measures the Irish State is currently taking to complete the waste management planning process will be identified.

\section{The Commission's Approach to Waste Management: Introducing the Waste Management Hierarchy}

Although altered in the course of a review in 1996, the main tenets of the EC's policy on waste management can be dated to 1989 when the Community strategy for waste management was adopted (Gallego, 2002). Three pieces of legislation to have derived from this strategy form the backbone of the Commission's policy. These are the Waste Framework Directive, the Directive on Hazardous Waste, and the Regulation on the Supervision and Control of Trans-Frontier Waste Shipments (European Environment Agency, 2000). The general legal framework provided by these three pieces of legislation is supplemented by a number of more specific Directives, dealing with particular waste streams (for example packaging waste, batteries and accumulators, waste oils, etc.), and setting safer technical standards for waste disposal and treatment facilities such as landfills and incinerators (European Environment Agency, 2000).

Central to the EC's approach to waste management planning are four key principles (Tormans, 2001): the proximity principle (which calls on each member state to take responsibility for disposing of waste itself and to refrain from exporting its problems elsewhere); the waste management hierarchy (which requires member states to produce comprehensive waste 


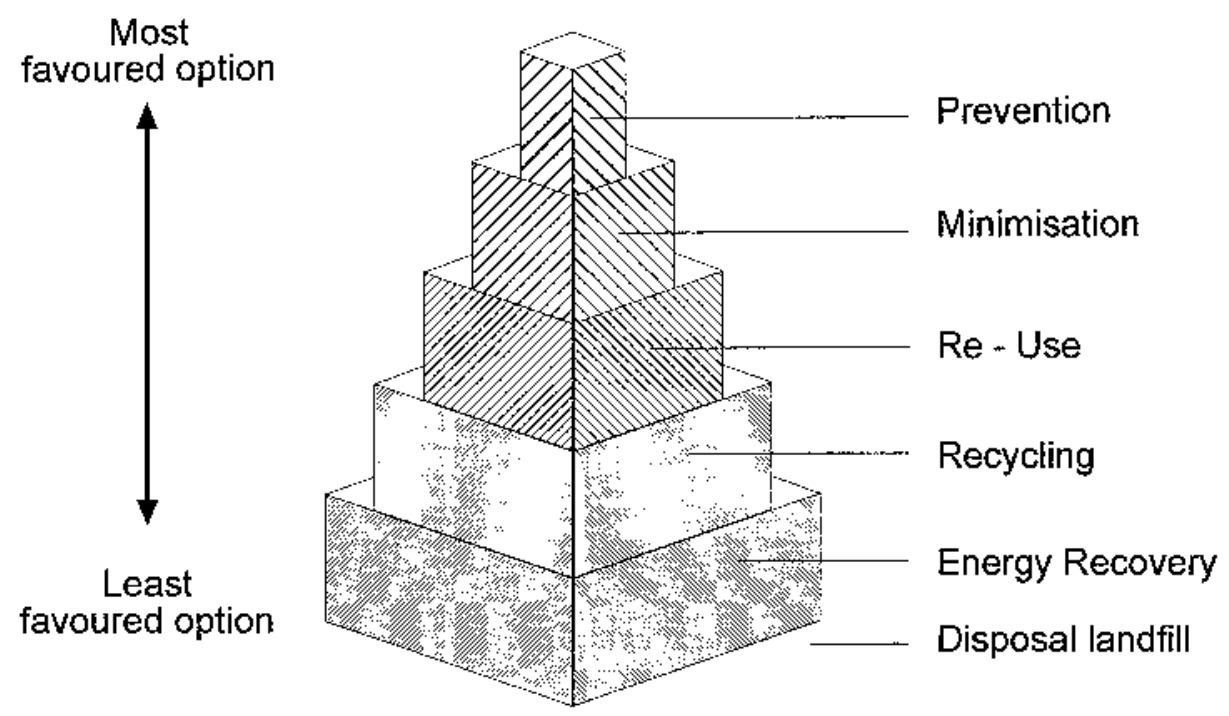

Source: Environmental Protection Agency, 2000a, p. 1.

Figure 1. The waste management hierarchy.

management plans that prioritize waste prevention, minimization and recycling/reuse options); the pre-cautionary principal (which demands that authorities in charge of waste processing, transportation, and disposal facilities, err on the side of safety even when scientific evidence on the level of toxic threat is open to debate); and the polluter pays principle (which asserts that producers of waste should bear the full brunt of waste treatment and disposal costs).

Of greatest interest here is the second principle of the waste management hierarchy - the central idea to derive from the Waste Framework Directive. The waste management hierarchy sets a list of priorities for dealing with waste (Figure 1). Priority must first be given to waste prevention and minimization through the application of technologies which produce cleaner production processes and which reduce packaging wastes produced at the point of consumption. To the extent that even the most efficient systems of production and consumption will generate waste, the next preferred options are the re-use and recycling of waste. Only in circumstances where it is impossible to re-integrate waste back into economic systems, should the issue of waste disposal be considered. In the event that disposal of waste is required, waste to energy or thermal treatment facilities should be prioritized as causing less environmental damage than the landfill solution which is identified as the strategy of last resort. The Waste Framework Directive requires member states to draw up waste management plans which detail how the waste hierarchy is to be implemented. Failure to produce such plans within a reasonable time frame can result in fines being imposed by the European Court of Justice.

\section{Ireland's Waste Management Problems: The Price of Success}

Whilst there is considerable debate over how to theorize Ireland recent growth strategy, there can be no doubts that this strategy has delivered incredibly rapid, double digit, world beating economic growth since 1993 (Figure 2). Irrespective if one attributes success to Ireland's embracing of neo-liberal approaches to economic governance under globalization (O'Hearn, 1998, 2000, 2001), or to the workings of a 'Tiger' like Flexible Development State (O'Rain, 


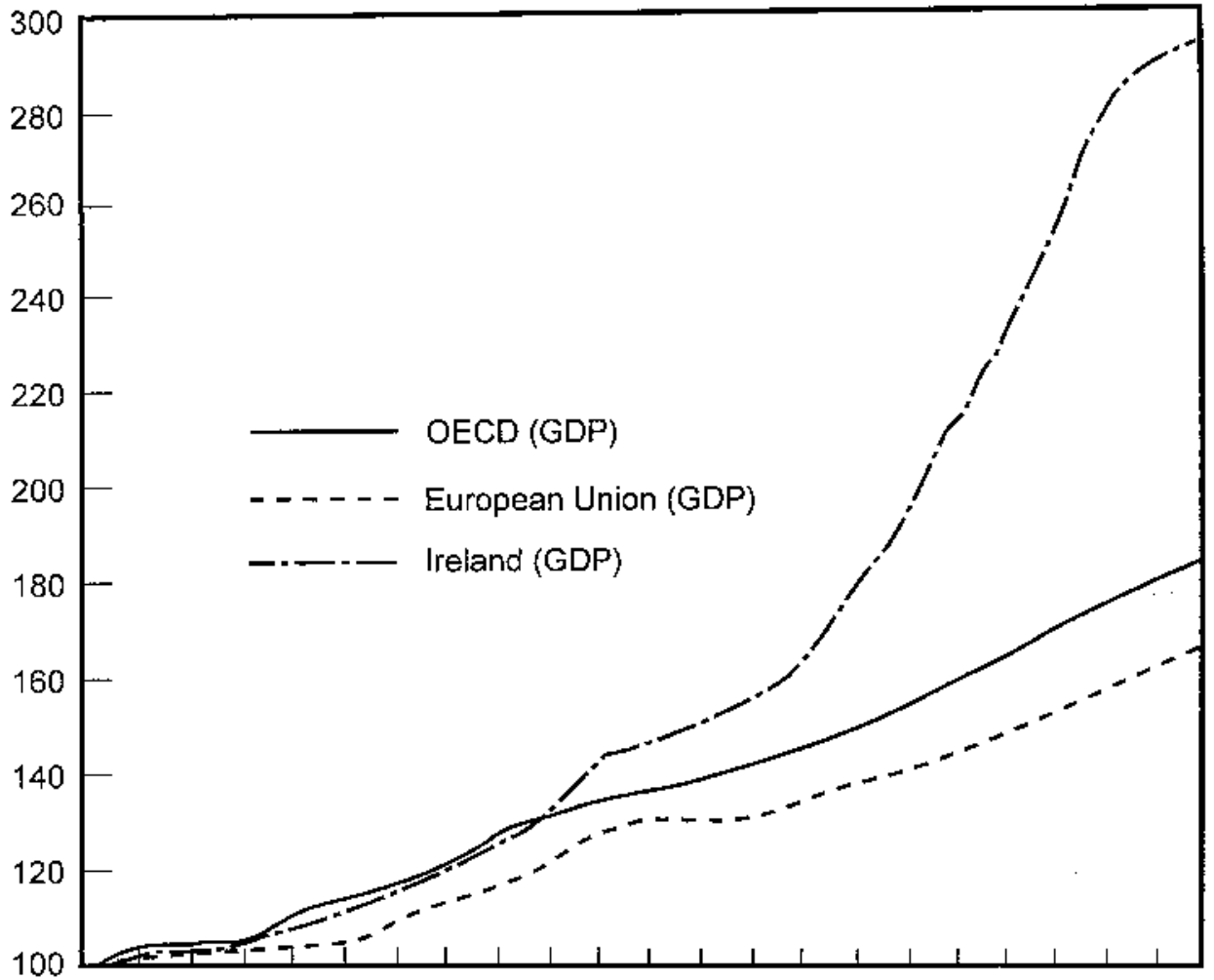

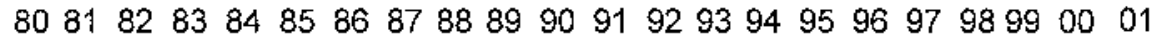

Source: International Monetary Fund, 2001, p. 4.

Figure 2. Ireland's economic performance in context: real output (indices; $1980=100$ ).

2000) harnessing the new entrepreneurial flair of Irish capital (Travers, 2001), it is clear that Ireland's economy has grown on the back of its capacity to ground and embed leading US transnational investment (particularly in the electronics and pharmaceutical sectors), and to foster the globalization of indigenous high-tech companies (Breathnach, 1998; Sweeney, 1999; Allen, 2000; MacSharry \& White, 2000; Travers, 2001).

Amidst the euphoria that has accompanied rapid economic growth, however, has been growing concerns about the volume of detritus which the Celtic Tiger is leaving in its trail. According to the OECD (1999, p. 156) 'waste' can be defined as materials for which the generator has at a given moment no further use for in terms of the processes of production, transportation, or consumption which they might be engaged in. Waste, therefore, consists of materials which are defined as residual to societal needs at a given moment in time and thus which require to be disposed off. Whilst waste can exist in liquid or gaseous form, the focus of this article will be upon solid waste. Moreover although agricultural wastes are numerically dominant in Ireland, they consist mainly of manure and slurry. Since these wastes are disposed of principally on farmland itself, they are not of primary interest here.

Five types of non-agricultural solid waste streams form the focus of this article. First, industrial waste 'includes waste produced or arising from manufacture or industrial activities or processes' (Environmental Protection Agency, 2000b, p. 93). Industrial wastes accrue from manufacturing plants, from energy, gas and water supply companies, and from mining and quarrying firms. Second, although not the exclusive preserve of the industrial category, an important relative of industrial waste is hazardous waste. These are wastes which, because of 
Table 1. Waste production in Ireland, 1995 and 1998

\begin{tabular}{|c|c|c|c|c|c|}
\hline $\begin{array}{l}\text { Waste } \\
\text { Category }\end{array}$ & $\begin{array}{l}1995 \\
\text { (Tonnes/annum) }\end{array}$ & Percentage & $\begin{array}{l}1998 \\
\text { (Tonnes/annum) }\end{array}$ & Percentage & $\begin{array}{l}\text { Percentage } \\
\text { increase } \\
\text { 1995-1998 }\end{array}$ \\
\hline Agricultural & 31000000 & 73.4 & 64578724 & 80.7 & +108.3 \\
\hline \multicolumn{6}{|c|}{ Non-agricultural wastes } \\
\hline $\begin{array}{l}\text { Industrial } \\
\text { Hazardous }\end{array}$ & 6092077 & 14.4 & 8835858 & 11.1 & +45.0 \\
\hline waste & 243754 & 0.6 & 370328 & 0.5 & +51.9 \\
\hline Municipal & 1848232 & 4.4 & 2056652 & 2.6 & +11.3 \\
\hline $\mathrm{C} \& \mathrm{D}$ & 2103508 & 5 & 3438958 & 4.3 & +63.5 \\
\hline Other & & & & & \\
\hline wastes & 961629 & 2.1 & 732158 & 1.5 & -23.8 \\
\hline $\begin{array}{l}\text { Total non- } \\
\text { agricultural }\end{array}$ & 11249200 & 26.5 & 15433954 & 19.3 & +37.2 \\
\hline Total & 42249200 & & 80012678 & & +89.3 \\
\hline
\end{tabular}

Source: Environmental Protection Agency, 2000b, p. 23.

their chemical composition, require different management strategies. Third, municipal wastes consist of both household and commercial wastes. Household waste is defined as 'waste produced within the curtilage of a building or self contained part of a building used for the purposes of living accommodation' (Environmental Protection Agency, 2000b, p. 93). Commercial waste in contrast, is waste 'from premises used wholly or mainly for purposes of a trade or business or for the purposes of sport, recreation, education or entertainment but does not include household, agricultural, or industrial waste' (Environmental Protection Agency, 2000b, p. 93). Fourth, construction and demolition waste incorporates waste produced by the building industry and includes dredge spoils. Finally, the category of other wastes, as employed here, refers to urban waste water sludges, drinking water sludges and end of life vehicles/scrap metal.

The relationship between economic growth and waste production varies according to the waste stream in question. Using regression analysis, the European Environment Agency (2000, p. 205) has recently argued for instance, that waste from the construction industries tend to be most sensitive to rates of national economic expansion. The correlation with wastes from the manufacturing sector, municipal sources, and finally hazardous materials, appears to be progressively weaker. Of course, the challenge overall is to attempt to de-couple waste generation from economic growth. In economies with 'cleaner' production systems such as Denmark and Germany, waste production is relatively low given levels of gross domestic product (GDP) and it is to the lessons offered by these economies that many European States ought to look as a starting point.

Any consideration of the extent to which Ireland's remarkable economic growth has served to produce more waste necessitates a reflection on the data sources available. Data on waste streams in Ireland derive from the National Waste Data Base Surveys. To date, two surveys have been undertaken, summarizing data for 1995 and 1998. Table 1 reveals trends in waste production in Ireland from 1995 to 1998. An increase in agricultural wastes of 103\% is noted. Non-agricultural wastes would also have appeared to have grown dramatically by over $37 \%$ in the 3 year period. In absolute terms industrial wastes would appear to have grown fastest, but in percentage terms, the growth of construction and demolition, hazardous, and municipal wastes is also noteworthy.

Because the 1998 survey worked on the basis of improved reporting systems, care must be 

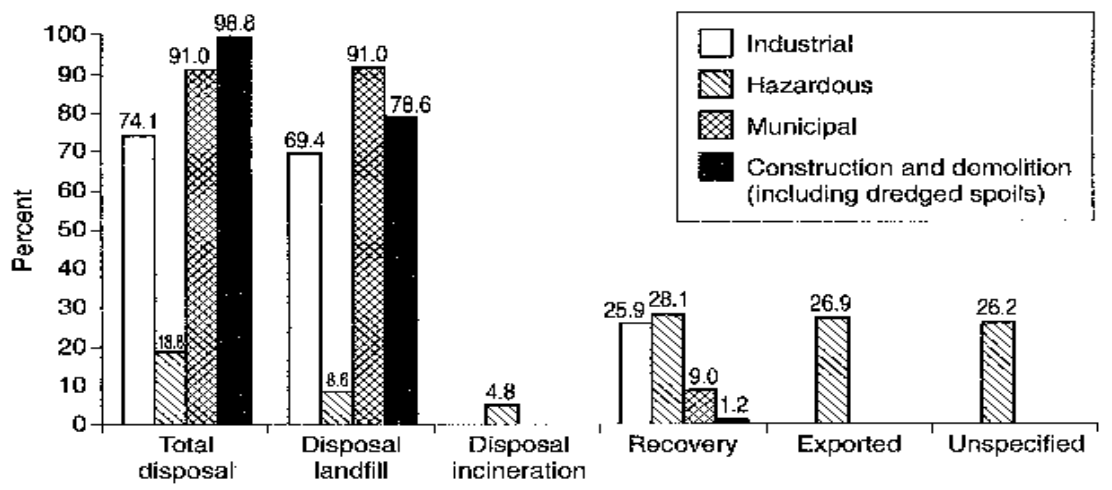

Notes: The EPA note that the amount of construction and demolition waste going to landfill is exaggerated since a substantial percentage of the material is put to beneficial use at the landfill location, either as construction for the construction of roads and berms or as cover and capping material. The large discrepancy between the total amount of construction material disposed of and the percentage that goes to landfill is accounted for by the dumping at sea of dredge spoils from harbour projects.

Source: Calculated from Environmental Protection Agency (2000b, Ch. 3).

Figure 3. Management of selected waste streams, 1998.

taken not to leap to any immediate conclusions about the magnitude of any increases in waste production. Nonetheless, whilst the latest National Waste Data Base Survey (Environmental Protection Agency, 2000b) acknowledges that altered recording procedures for agricultural wastes explain the bulk of increases experienced by this sector in particular, for non-agricultural waste streams, it argues; 'based upon specific waste streams, where historical data is considered to be reasonably reliable, waste quantities appear to be increasing more or less in line with economic growth' (Environmental Protection Agency, 2000b, p. 23). Consequently, whilst shifts in non-agricultural wastes partly reflect improved auditing, the latest survey concludes that even within a short period of 3 years, economic growth has significantly increased waste streams in Ireland.

\section{A Radical Departure? Waste Management Planning in Ireland Since 1996}

Prior to 1996, Ireland's approach to the management of all of the above waste streams can accurately be described as piecemeal and unimaginative. Traditionally, waste management has been a reserve function of local government. In Ireland's unique system of local government, reserve functions refer to functions of local government that are the responsibility of elected representatives (reserved for councillors), as opposed to 'executive functions' which the responsibility of the County Manager, a powerful civil service position within Irish counties. This allocation of responsibility for waste management to local councillors was later to become a key issue in the emerging waste management planning process.

Echoing trends across Europe, waste management in Ireland pre-1996, was overwhelmingly conceived in terms of waste disposal in general and landfill in particular (Figures 3 and 4). Also echoing trends across Europe, a general lack of politicization of waste disposal marked the waste management process. Publicly run landfills might have been poorly run, low-tech, and a blot on the landscape but a general dearth of eco-consciousness pervaded the political system. In any event, the volumes of waste involved meant that the need for new landfills was a limited and parochial issues and was not a phenomenon that inspired national debate. Against the context of such primitive waste management infrastructure, rapid economic growth, surging increases in waste volumes, and new EC legislation, however, the Minister for the Department of Environment and Local Government launched a radical overhaul of waste management planning in Ireland. 


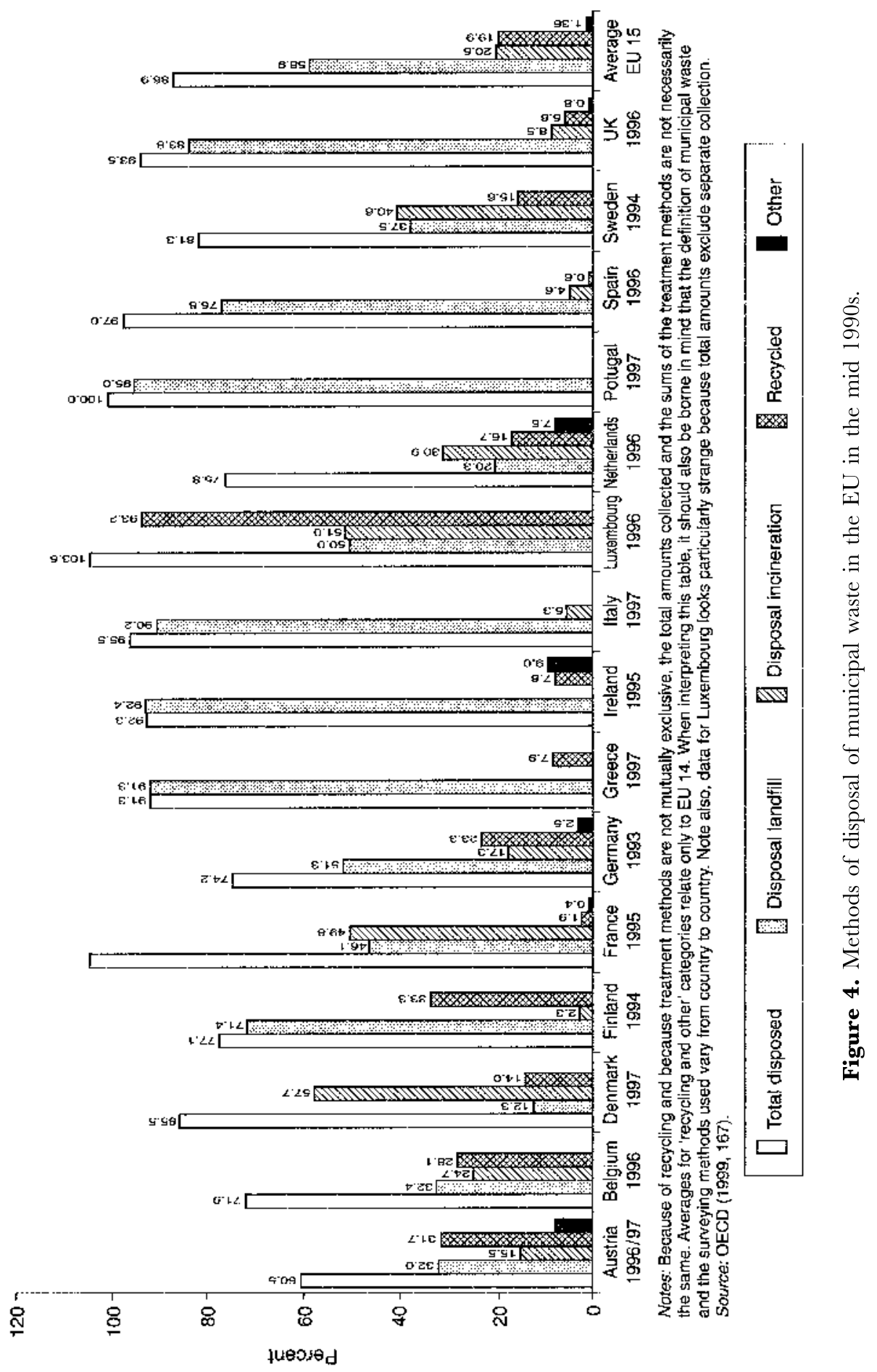


Table 2. 'Changing our ways': targets to be achieved over a 15 year time-scale

- A diversion of $50 \%$ of overall household waste away from landfill

- A minimum $65 \%$ reduction in biodegradable wastes consigned to landfill

- An $80 \%$ reduction in methane emissions from landfill

- Rationalization of municipal waste landfills, with progressive and sustained reductions in numbers leading to an integrated network of some 20 state-of-the-art facilities incorporating energy recovery and high standards of environmental protection

- The development of waste recovery facilities employing environmentally beneficial technologies as an alternative to landfill, including the development of composting and other feasible biological treatment facilities capable of treating up to 300,000 tonnes of biodegradable waste per annum

- Recycling of $35 \%$ of municipal waste

- Recycling of $50 \%$ construction and demolition waste within a 5 year period, with a progressive increase to at least $85 \%$ over 15 years

Source: Department of Environment and Local Government, 1998b, pp. 6-7.

The new departure was first announced in the Waste Management Act which came into effect in July 1996 (Department of Environment and Local Government, 1998a), and was given more detailed expression in the Waste Management (Planning) Regulations (1997), and the policy statement 'Waste Management, Changing our ways ...' published in September 1998 (Department of Environment and Local Government, 1998b). The professed ambition of the new strategy was a shift away from landfill and towards implementation, in so far as it was practicably possible, of the EU waste management hierarchy. Indeed, in the 'Changing our Ways' document, the government set a number of specific targets to be achieved over a 15 year cycle to give tangible expression to this aspiration (Table 2).

At the heart of the new strategy was the formulation of waste management plans. Given the relatively small amounts of hazardous waste Ireland produces (not to mention the specific dangers associated with such waste), it was felt that a national strategy was required to secure the economies of scale necessary to increase waste management options for this specific stream. Consequently the Environmental Protection Agency, the State's environmental watchdog, was put in charge of developing a National Hazardous Waste Management Plan (Environmental Protection Agency, 1999). Responsibility for producing non-hazardous waste plans however, was to continue to be vested in local authorities.

From the outset, concern was expressed that the small size of local authorities threatened to undermine their capacity to act. Consequently, the new strategy advocated a regionalization approach whereby economies of scale were to be obtained through local authorities grouping together to formulate a regional plan. The need to manage the larger volumes of waste which would result would facilitate the development of recycling/reuse infrastructure and, more to the point, would create a sufficient market to support small waste to energy facilities. It would also assist in the movement away from a large number of small and low technology landfills to a smaller number of larger and better run landfills - later to be stigmatized as 'super-dumps'.

The Irish State has historically been characterized by a very strong national government and a weaker system of local government based upon the country's 26 counties (Figure 5). Despite some lip service, Ireland has and is bereft of any meaningful system of regional governance. Not only are existing regional institutions flimsy and largely irrelevant but the notion of the 'region' is a culturally meaningless one in Ireland (Coyle \& Sinnott, 1992; Laffan, 
1 Northern Ireland and Donegal

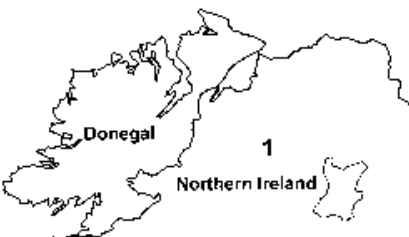

2 North East

3 South East

4 Dublin

5 Midlands

6 Wieklow

7 Kildare

B Cannacht

9 Cork

10 Midwast
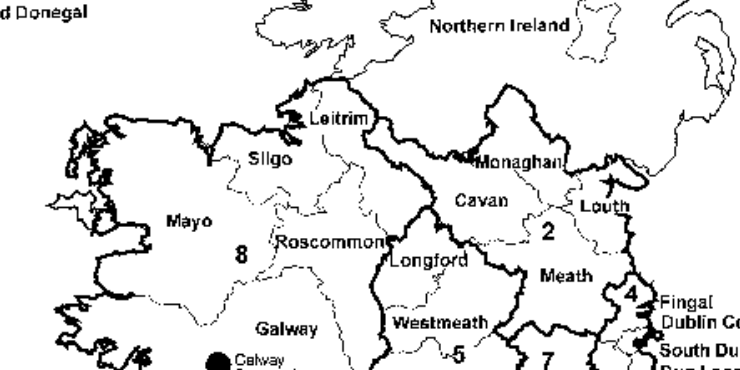

Wayo
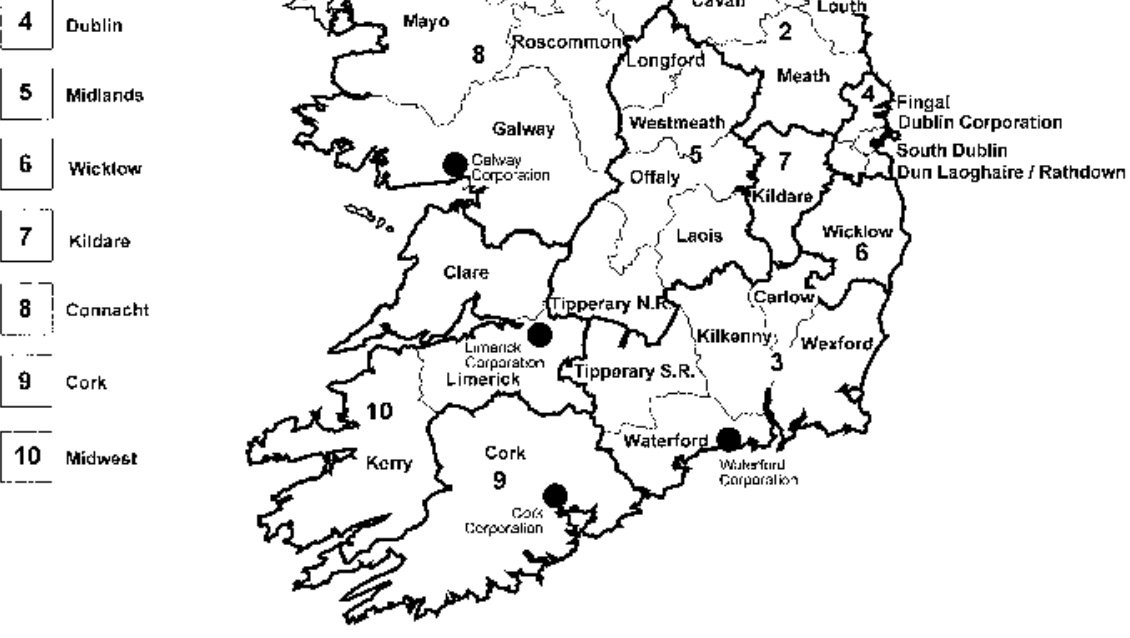

Source: The Irish Times, 10 January 2001, p. 9.

Figure 5. Regional waste management planning areas in Ireland.

1996; Boyle, 2000). For instance, it would be fair to say that even the four ancient provinces of Munster, Ulster, Leinster, and Connacht, which lack institutional significance in any event, resonate only weakly within the contemporary Irish territorial imagination.

Given the lack of a regional tier of governance in Ireland, whilst the regionalization strategy was advocated it was not forced upon local authorities and it was up to each authority to determine whether they wished to be in a regional grouping and if so which other local authorities they wished to link up with. In the end, a total of seven regional groupings comprising 31 of Ireland's 34 local authorities formed to prepare a joint plan (Figure 5). Both Wicklow and Kildare County Councils opted to remain outside regional plans in the hope that they might selectively buy into the Dublin regional plan at a later date. Finally Donegal County Council was to join Northern Ireland in the preparation of a cross-border plan.

In recognition of their lack of expertise in waste management planning, all the new regional groupings were obliged to employ specialist consultants to prepare draft plans. This task fell to Irish engineering consultants M.C. O'Sullivan and Co. Ltd, who produced all but one of the regional plans. That such a task should be entrusted almost exclusively to one particular consultancy ought immediately to raise a number of questions. Perhaps this firm really were the only qualified company in the country with the necessary expertise. Nonethe- 
less, the company's links with the Irish State, key factions of capital, and the waste disposal industry more specifically, clearly merits attention. This is a task which nonetheless falls beyond the remit of the present article.

Once formulated, these draft plans were to go out for public consultation. Each local authority would then have to vote to accept the plan for their region and plans would be rendered illegal unless all members of the group accepted them. Given the 4 year cycle in which to complete the entire planning process from design to implementation, draft plans were prepared and published for public consultation in the course of 1997 to 1999.

It should be noted that in all cases in which they were involved, consultants embraced the ethos of re-use/recycling and all draft plans had detailed recommendations on the types of infrastructure required to maximize re-use/recycling. Key to each plan however, was the belief that it was unrealistic to think that re-use/recycling could solve all of Ireland's waste problems - even with the best will a significant amount of waste required to be disposed of (Rudden, 2000). Accepting EG thinking that waste to energy was a preferable method of disposal to landfill, key to all of the plans was a proposal to construct at least one thermal treatment facility in each regional grouping. To the extent that landfills were still required, plans worked towards a steady reduction in the total number of landfills and the creation of 'super-dumps' with higher operating standards.

According to the Department of Environment and Local Government (2000, p. 29), a 'typical' regional plan aims to recycle $51 \%$ of total waste, dispose of approximately $27 \%$ through incineration, and landfill only $22 \%$. In practice however, some plans have had more modest recycling targets and thus have been forced to consider higher thermal treatment volumes. In the Mid-West, North-East, Midlands, and Connacht for instance, 45, 39, 37, and $33 \%$ of waste is planned to be thermally treated, respectively (The Irish Times, 2001a, p. 10). It has been this relative lack of emphasis upon waste minimization and prevention, and the continued importance placed upon incineration and landfills that has served to generate most controversy. For many, the regional waste management plans have failed to engage with the spirit of the concept of the waste management hierarchy and ought to be read as little more than an attempt to absorb international environmental obligations without damaging the accumulation strategy that has delivered success.

\section{Why 'Scale' Matters: Scale as an 'Active Progenitor' of Waste Management Planning}

A central argument advanced in this article is that the decision by the Irish State to manufacture a new configuration of regional waste management planning areas in the country has proven crucial to the kinds of waste management policies and practices which have subsequently been envisaged. Moreover, consistent with the concept of the scalar dialectic, the regionalization strategy in turn has set the scene for a struggle over waste management planning and a potential structuration of the scale division of the planning process. As such, scale needs to be approached as an 'active progenitor' (Smith, 1993, p. 101) of Ireland's contested grounding of the waste management hierarchy. In an effort to think through precisely why and how scale matters in this context, this section aims firstly to consider the claim that by 'fixing' waste management planning at the regional level, the Irish State has attempted to appropriate the waste management hierachy in such a way as to protect and defend the imperatives of accumulation. This section will also then reflect on the idea that 'scale' is not only implicated in the defence of accumulation but paradoxically can also be an 'active progenitor' of conflict and threats to accumulation. 


\subsection{The 'Benefits' for Irish Capital: In Defence of the Accumulation Strategy}

One reading of the effort to 'scale' the problem of waste management at the regional level might be to view it as an attempt by central government to cleanse itself of any responsibility in the making of regulatory decisions which are more friendly to the chosen accumulation strategy than to local communities around the country. If the Irish State was to avoid imposing additional burdens on the capital, it had to ensure that options at the bottom of the waste management hierarchy were promoted (mainly incineration and new 'super-dumps'). Vigorous pursuit of options at the top of the hierarchy, in particular measures to reduce the total waste produced by industry, ran the risk of scaring off potential investment. The imposition of incinerators and super-dumps on local communities however, would clearly be a controversial measure. Regionalizing the problem constituted a potential displacement of responsibility and would take the pressure of the Central State.

This point was not lost on opposition parties. In a heated debate in the Irish Seanad in March 2001, Senator Brendan Ryan, noted that by constructing a division of labour between central and local government, national politicians could create a distance between themselves and the difficult decisions which had to be taken concerning how economic growth needed to be managed and regulated:

This is not a technical issue ... It is a political crisis because those who wish to claim all the credit for our economic success will not take the responsibility for its consequences which they want to pass on to others... While central government wants to take the credit for the wonderful performance of the last few years, it wants local authority members to take the stick for the negative side, the explosion of waste ... It is up to those who claim the credit for creating the good times to take responsibility for them. I do not blame local authority members who see themselves as being hung out to dry by central government. While claiming credit for the good things, it has told them to produce a waste management plan and decide to do things for which it will not accept responsibility. Underfunded local authorities are supposed to take the heat while the Minister makes eloquent speeches about the environment in the abstract. This is an issue about political leadership. It is a national issue that must be solved locally, but it must be led from the top. (Senator Brendan Ryan, Labour, Seanad Debates 28 March 2001)

More profoundly however, it might be argued that by regionalizing waste management planning, the Irish State has carefully crafted an institutional structure that is more capable of delivering options at the foot of the hierarchy and less capable of pursuing options further up the hierarchy. One self-professed 'logic' of regionalization advanced by the Irish State is that it helps create economies of scale sufficient to make incineration and super-dumps viable. In otherwords, the volumes of waste generated by individual counties are unlikely to attract private companies keen to build incinerators and super-dumps; the greater volumes generated at a regional level opens up new market opportunities to the waste management industry.

However, it is self evident that weak and fabricated regional groupings of local authorities lack both the power and competence to force the main drivers of the Celtic Tiger into using cleaner technologies. In a highly centralized State such as that which prevails in Ireland, the kinds of eco-taxation schemes open to regional groupings in their efforts to pursue a strategy of waste prevention and minimization are clearly limited (Turner et al., 1998). It is doubtful that a uniform taxation could be secured across local authority groupings and even if this were possible, competition for investment between groupings would mitigate against penal measures. In contrast, it could also be argued that it is only when waste management is scaled at a highly local level (city, community, or even street level), that recycling and/or re-use 
measures become effective. If forced to deal with their own waste rather than pass responsibility over to some larger abstract authority, arguably the general public might display a greater desire to recycle and compost.

A case can be made therefore, that projects which might make a serious contribution to addressing the most favoured prevention/minimization, and re-use/recycling options need to come from either central government or much smaller units of governance. What is clear nonetheless, is that the agenda of economic growth has not been seriously threatened or undermined by Ireland's post-1996 'regional' waste management strategy. If anything, regionalization has promoted forms of planning that support capital. It would seem fair to conclude that waste management planning in Ireland appears to have been more concerned about organizing consent around what are acceptable levels of pollution, and what might minimize damage to the country's remarkable economic growth, than radically attacking the roots of the economic policies and systems that generate problems of waste in the first instance (Taylor, 1998).

\subsection{Threats to the Accumulation Strategy: Why Regionalization has made it Harder to Sweep Irish Waste under the Carpet}

It is somewhat paradoxical that it has been precisely the same regionalization strategy that has allowed the Irish State to walk the tightrope between satisfying EU rules whilst privileging national economic growth, that has served to grind the waste management planning process to a halt. Over the past 2 years, a plethora of local opposition movements have grown in Ireland, keen to pressurize local politicians into rejecting the proposed regional plans. These movements have been highly successful in frustrating the capacity of the Irish State to complete the planning process. By late March 2001 for instance, three local authorities in particular; Longford County Council (Midlands) group, Louth County Council (North-East) and Galway County Council (Connacht), had rejected plans in their entirety holding up the remaining 12 local authorities in their groupings. Other local authorities meanwhile, such as Wexford County Council (South-East) and Roscommon County Council (Connacht), had adopted plans only subject to potentially significant qualifications relating to the incineration option.

Whilst the regionalization strategy has made possible incineration and superdump options that would simply not be feasible at a county level, it has also created the spectre that given that only one or two counties in a regional grouping might play host to these disposal facilities, only one or two communities might need to bear the brunt of a whole region's waste. This possibility has animated a multitude of local resistance groups. Fearing the electoral consequences of accepting responsibility for other counties' waste, local politicians in those counties earmarked for an incinerator or a super-dump have found it difficult to vote through plans and have become involved in increasingly bitter exchanges with national government. At the heart of these exchanges has been the matter of the health hazards of both incinerators and super-dumps.

The case of the Connacht regional plan serves to illuminate the difficulties the Irish State has faced in completing the planning process. The Draft Waste Management Plan for Connacht (1999-2004), produced jointly by M.C. O'Sullivan and Co. Ltd. and Danish consultants COWI, was published in September 1999 (M.C. O'Sullivan and Co Ltd, 1999). The plan was to cover non-hazardous waste management in six local authority areas in the Connacht region; Galway, Mayo, Sligo, Leitrim and Roscommon County Councils, and Galway Corporation (Figure 6). As with other plans prepared by M.C. O'Sullivan, thermal treatment was to be a central feature of the plan. By 2013, 48.1\% of Connacht's waste was to be recycled, $32.7 \%$ thermally treated, and $19.2 \%$ landfilled. The inclusion of landfills and 


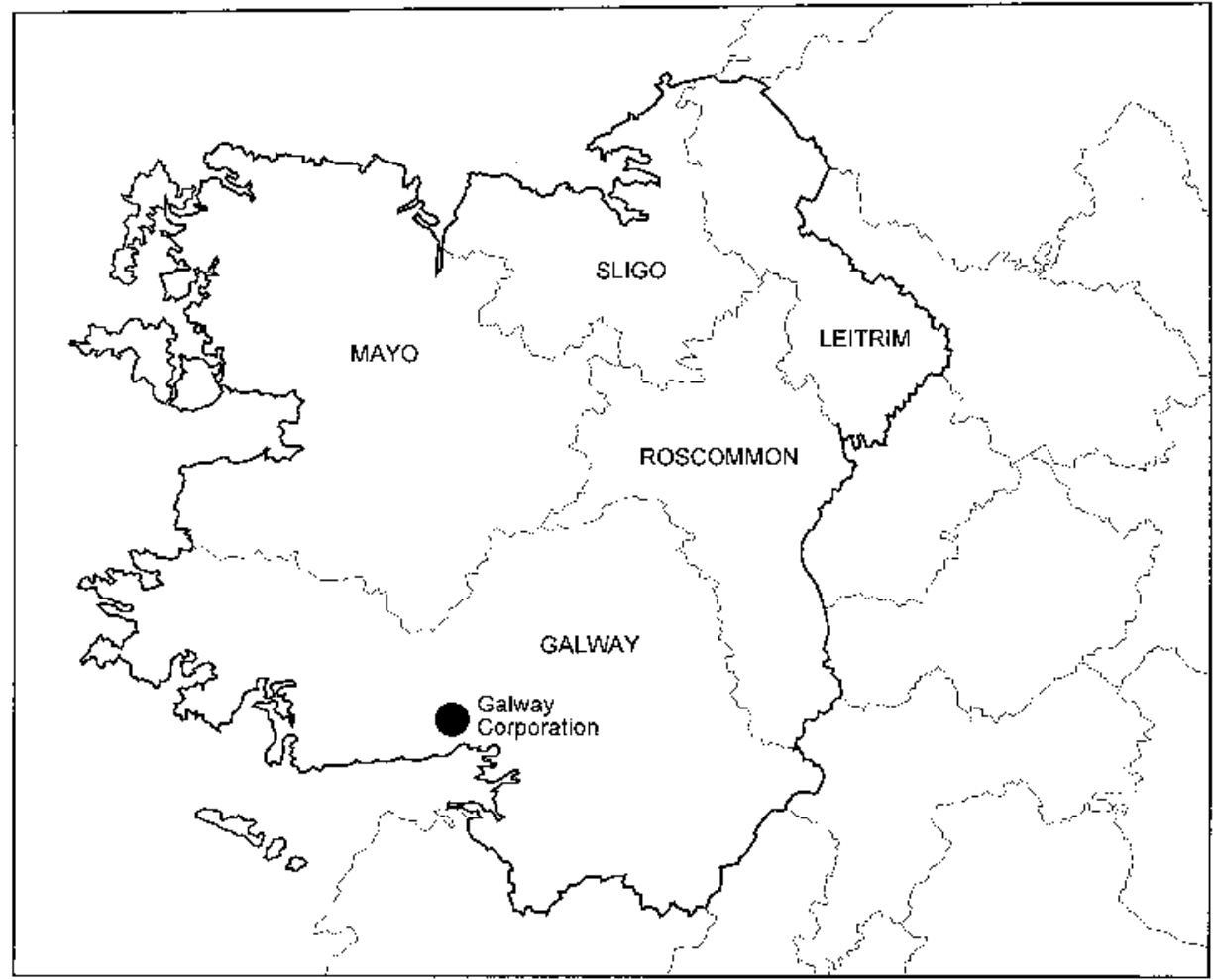

Source: The Irish Times, 10 January 2000, p. 9.

Figure 6. Connacht waste management planning area.

incineration as an integral part of the plan was to unleash vocal local opposition. This opposition was fuelled by the fact that the plan explicitly identified Galway city as the location for the proposed incinerator. Not surprisingly, it was Galway County Council and Galway Corporation that had most difficulty with the plan.

At the leading edge of local opposition was the Galway Safe Waste Alliance (GSWA). This organization comprised a coalition of six different community groups with environmental concerns, of which perhaps the most prominent was Galway for a Safe Environment. In part informed by critiques of the plan advanced by the national Waste Working Group (a coalition of environmental non-governmental organizations (NGOs) led by VOICE of Irish Concern for the environment and Earthwatch: Friends of the Earth Ireland (Waste Working Group, 2000)), GSWA sought to move beyond allegations it was motivated by NIMBY concerns. In their various submissions to both the Connacht regional authority and Galway County Council and Corporation more specifically, GSWA called for the plan to be rejected because it failed to justify why incineration and landfills were needed and failed to reflect properly on the possible health hazards of both. Galway's waste it was argued, could be better handled through the development of a vastly improved recycling/re-use infrastructure. A number of initiatives were taken to promote this agenda including: oral presentations to both of Galway's local authorities; the submission of a 22,122 signature petition; the encouragement of 2600 individual submissions from concerned people; inviting to Galway Professor Paul Connett of St Lawrence University, New York, a well known critic of incineration; hosting a series of public meetings and debates; the development of an up to date web site; and the staging of silent protests as counsellors met to discuss the plan. 
The health hazards of living in the proximity of an incinerator emerged as perhaps the most emotive issue championed by protestors. In particular, debate focused upon the main contaminants released in the combustion process, dioxins. Airborne dioxins produced from incinerator plants, it was argued, were capable of affecting health both directly through inhalation, and indirectly, by becoming absorbed in the food chain. The problem of dioxins was compounded by the need to landfill slag laced with a number of dangerous heavy metals which remained after incineration. Both risks were seen as hazardous enough to merit a rejection of the incineration option. There can be no doubt that increases in dioxins in particular ought to cause significant alarm. According to the Midland Health Board (2000, p. 52):

Short term exposure of humans to high levels of dioxins may result in skin lesions, such as chloracne and patchy darkening of the skin, and altered liver function. Long term exposure is linked to impairment of the immune system, the developing nervous system, the endocrine system, and reproductive functions. Chronic exposure of animals to dioxins has resulted in several types of cancer.

The key question however, was whether incinerator technology was advanced enough to ensure that levels of dioxin pollution were safe.

The chief environmental problems with landfill sites relate to the leaching of nutrients, heavy metals, and other toxic compounds from landfill locations into the water table, and the emission of greenhouse gases, particularly methane and carbon dioxide. Clearly, the extent of these problems vary according to the location and design of the landfill. Nevertheless, they have been taken sufficiently seriously to have generated a lively discussion in Connacht (and Ireland more generally) about the public health consequences of living close to a super-dump. Although the evidence is inconclusive, concerns have been expressed about the possibilities of adverse pregnancy outcomes (including low weight babies) and reported increases in certain types of cancers (see Midland Health Board (2000) for an excellent summary of the debate).

Against the backdrop of local opposition, Galway Corporation voted to reject the plan on 26 July 2000. Galway County Council followed suite and on 1 September 2000, also voted to reject the plan. These rebuffs proved to infuriate the government. In a visit to Galway on Friday 19 January 2001, Minister Noel Dempsey 'expressed serious concern' about the Galway situation and threatened to take 'direct action' if both local authorities in Galway did not act to complete the planning process (The Irish Times, 2001b, p. 12). In particular he threatened to pass on the full costs of any fines the European Court of Justice might levy, to both local authorities. In a more general statement made around the same time, Dempsey protested:

It is particularly galling to think that unnecessary fears are being raised and expert opinion is being ignored, credible statistics are being distorted, reports from the World Health Organization, European and UK sources are being discounted and rubbished by people to advance their own political agenda ... On the one hand, we have an alliance of doctrinaire greens who appear out of touch with their European counterparts and who propose hopelessly impractical solutions to our waste problem. I have spoken to Green Ministers in Germany and France and neither of them has a problem with properly run and properly regulated incinerators. We also have globe trotting self appointed 'experts' supplying a niche market with stock, simplistic answers, usually based on the experience of the 1960s and 1970s. We have political opportunists, who are happy to jump on any bandwagon they believe to be populist and that might get them elected. We have groups clearly motivated by the NIMBY 
agenda. (Noel Demspey, Fianna Fáil TD for Meath, Minister for Environment and Local Government, Seanad Debates, 28 March 2001)

On 5 February 2001, under pressure from the government, Galway Corporation voted to overturn their initial decision and on a vote of 8-7 agreed to accept the plan. To the GSWA, this U-turn was nothing short of betrayal. According to 'Galway For a Safe Environment' spokesperson, Dr Conchur O’Bradaigh:

this incredible U-turn was taken under severe pressure from ... the Minister for the environment, Noel Demspsey ... It represents a total betrayal of the people of Galway, 25,000 of who lodged objections against this plan last summer. This issue will now become a major one in both Galway West and Galway East constituencies in the forthcoming general election. (Galway for a Safe Environment web page http://go.to/gse (accessed May 2001))

Defiant and undeterred nevertheless, Galway County Council unanimously rejected the Connaught waste management plan for a second time on 9 April 2001, arguing that concerns about the public health risks of incineration had still not been properly addressed by the minister. Noel Dempsey was accused by independent Cllr. Pat Hynes of being "undemocratic, vindictive, and dictatorial in trying to ram the Connacht plan down the throats of people" (The Irish Times, 2001c, p. 8).

This case study of the difficulties the Irish State has had in trying to enforce a regional planning strategy in Connacht captures exactly the concept of the scalar dialectic inherent in waste management planning. Whilst this strategy has delivered a plan that largely ignores waste prevention and minimization, and which continues to foreground capital friendly methods of waste disposal, it nevertheless contains within itself a defect that has threatened to become its downfall. By creating the scenario that one or two communities will need to pay the price for the economic success enjoyed by the entire region, and by introducing the methods of incinerators and super-dumps into the equation, the regionalization approach has stimulated types of protest groups and forms of protest that might not have existed at all, or if they did, might have assumed a different guise and vehemence if an alternative scaling of the planning process had occurred.

\section{Bringing the Militants to Order: Preserving the Regionalization Strategy}

Faced with mounting criticism that he had failed to show sufficient national leadership, that the planned 4 year deadline for plan implementation was about to pass, and under the threat of sanctions from the European Court of Justice, Minister for the Environment and Local Government, Noel Dempsey, made a decisive intervention in March 2001 in the form of the Waste Management (Amendment) Bill 2001. This Bill, which proposes a number of draconian measures designed to bring the planning process to completion, has proven to generate further controversy.

Introducing the Bill to the Seanad on 28 March 2001, the Minister explained the need for new measures:

It would make a mockery of my stewardship of the environment brief to allow the current drift to continue. We have lost too much time. We have to act now to put a modern and efficient waste management infrastructure and improved waste services in place. I was castigated last week by some of the parties which tabled the motion for allowing this to go on as long as I have, but I gave fair warning and the time to act is now. I have to act in the overall national interest to take the steps that will facilitate the satisfactory completion of the planning process. (Noel Demspey, 
Fianna Fáil TD for Meath, Minister for Environment and Local Government, Seanad Debates, 28 March 2001)

At the centre of the Bill was a proposal to transfer the power to adopt a waste management plan away from locally elected members of local authorities to local authority managers - in other words to remove waste management as a reserve function. By giving executive authority to the local civil service machinery, which was insulated from electoral pressures, the Minister hoped to 'remove any perceived obstacles to the effective implementation of regional plans'. If local counsellors lacked the nerve the push through unpopular plans then responsibility to make difficult decisions required to be relocated elsewhere.

Not surprisingly, the proposal generated a furious response from both local politicians and national opposition parties (particular Fine Gael and Labour). At the heart of local opposition was the question of the erosion of local democracy. Plans which were produced by private consultancy firms for local democratic review and critique were now to be given, it seemed, the de facto status of legal and binding regional plans. To some, the Minister seemed more determined to force through unpopular plans than to take seriously local concerns about the dangers of incineration and landfill. Fine Gael, Senator Fergus O'Dowd for instance, tabled a motion in the Seanad on 28 March 2001 moving:

That Seanad Eireann condemns the Minister for the Environment and Local Government for his proposals on waste disposal; and demands that before any final decisions are taken, the Minister enters into a full debate on all the issues involved, especially the possible health hazards of incineration. (Senator Fergus O'Down, Fine Gael, Seanad debates 28 March 2001)

Responding to these allegations, Minister Noel Dempsey argued that the Bill actually strengthens local democracy because it restricts the capacity of a minority of local authorities to slow down the capacity of the majority of local authorities who have already accepted plans to get these plans implemented. Perhaps the most telling reading of the Bill however, has come from Independent Senator Shane Ross. Unbound by the constraints of party politics, Senator Ross accepted that local democracy was being undermined but in contrast to other Senators publicly welcomed that fact:

I congratulate the Minister for undermining local government. I wish he would say he is doing that and why. He mentioned ... cases ... where local representatives were defying the regional plan. What else does he expect them to do? He wouldn't expect them to destroy special areas of their own counties ... County Councillors ... have proved themselves totally unfit to deal with this matter because their knee-jerk reaction to the suggestion that a dump be put in their area is to say 'no'. They will say their area is unsuitable and invent reasons for not putting it there ... There are certain issues on which local politicians should not be asked to judge. It is quite obvious that they cannot judge these issues. (Senator Shane Ross, Independent, Seanad Debates, 4 April 2001)

In other words, regionalizing waste management and therein expecting one or two communities to absorb the problems of an entire region's waste was always going to be doomed to failure. Inherent in the scalar strategy was the seeds of its own downfall. Only through draconian enforcement might the strategy work. Although weathering a stormy passage, the Waste Management Amendment Bill successfully passed through the Seanad in April 2001 and was passed into law by the Dáil in July 2001. Whilst County Managers have now brought the planning process to completion, it nevertheless remains an open question as to whether plans foisted on unwilling communities can actually be implemented. Struggles over inciner- 
ators and super-dumps in Ireland are still at their dawn, even if the planning process appears to have made it through to dusk.

\section{Conclusion}

Countries across the EU are currently trying to grapple with the thorny question of how to engage with the EC's principle of the waste management hierarchy. Even a cursory glance reveals that in reworking this principle into different national contexts, member states have been active in bending and twisting its essential ambitions so that at times it seems almost unrecognizable. The purpose of this article has been to outline a theoretical perspective that might help researchers interested in mapping and explaining the metamorphosis of the concept of the waste management hierarchy as it embeds itself in different national settings.

Locating the grounding of the waste management hierarchy against the backdrop of the overwhelming focus of member states on protecting and indeed nurturing their own accumulation strategies, this article has called for increased attention to be given to the scalar constitution of waste management planning. All over Europe at present, the scalar scaffold through which environmental governance in general, and waste management planning in particular, is executed is being re-examined. In part as a result of the different accumulation strategies that are being pursued across Europe, the results of this re-examination are complex; with cobwebs being blown away from existing arrangements, with existing scalar structures being re-animated in entirely new ways, and with virginal scalar scaffolds being erected afresh.

The core thesis advanced in this article is that greater attention ought to be given to the scale divisions of waste management planning which are currently crystallizing out. The scalar constitution of waste management planning serves as a motor force in shaping the kinds of transpositions of the waste management hierarchy that are both possible and desireable for different interest groups. As the case study of the Celtic Tiger has shown however, particular scalar structures can serve both as a bolster to accumulation strategies (reducing the potential burdens of the waste management hierarchy on Ireland's US transnational base and high-tech indigenous companies) and paradoxically as a stimulant to groups opposed to capital friendly forms of waste disposal. Scale serves to generate a dialectical process of planning/resistance/ re-planning and so on and as such must be regarded as an active progenitor of the structuration of the concept of the waste management hierarchy in different national settings.

A new research agenda for those interested in waste management planning in the EU thus perhaps now presents itself. This agenda might begin with a descriptive mapping of the different scalar scaffolds responsible for waste management planning in different countries. The different types of engagements with the EC's concept of the waste management hierarchy might then be charted, with particular attention given to how the scaling of the 'problem' has conditioned the various options open to planners and framed the mind sets that underpin how they approach the task of planning. This then would lead logically to the most crucial question of all; who ultimately has the power to act as midwife and husbandry to particular scalar structures in different member states. Are social/political/economic constituencies at work, and at work in different ways, with different degrees of influence, in different States? If so, in what ways does the location of these actors within different national accumulation strategies appear to make a difference? As national accumulation strategies evolve, and as power blocs shift, how do the scalar hierarchies of waste management planning evolve and with what effects?

In conclusion, this article has demonstrated that in seeking to theorize the rise of multi-level governance in Europe from a perspective that views scale as a social process, attention needs to be given to the distinctive political ecologies as well as the political 
economies of member states. This dual focus might well be revealing in so far as the kinds of scalar structures which serve dominant interests in the context of the latter might not be useful in the case of the former. A substantial literature now exists for instance, pointing to the reluctance of many central governments to buy the Commission's vision of a 'Europe of the Regions' - in spite of drawing down substantial Structural Funds which are conditional on strong regional planning mechanisms being in place (Hooghe, 1996). Ireland is arguably the worst culprit in this regard. Whilst being a major net beneficiary of Structural Funds to date, Ireland remains one of Europe's most centralized States and refuses to erect meaningful regional authorities for Structural Fund planning (Boyle, 2000). Against this backdrop, the complete resistance of the Irish State to develop a national waste management strategy, and the draconian measures it has taken to force regions to 'plan for themselves' seems all the more remarkable. Regions it would seem, only matter when it comes to taking responsibility for environmental damage.

\section{Epilogue}

At the time of writing (September 2004), Ireland's economic miracle looks to be on the wane. Affected by the US recession, Irish economic growth in 2002 will be the lowest for a decade. OECD (2002) estimates, for instance, suggest a fall in GDP growth rates from $10.4 \%$ in 2000 , and $6 \%$ in 2001 , to $3.5 \%$ in 2002 (see also Clinch et al., 2002). Whilst this slow down was predicted, at the beginning of 2002 it was projected to be a temporary phenomenon. Inspired by the anticipated resurgence of economic growth in the US, the OECD (2002) for instance predicted a resumption of solid growth in 2003 with a GDP growth rate of $6.3 \%$.

More recently however, more sober and less optimistic economic assessments have been published. In the Irish State's own and latest Economic Review and Outlook (published September 2002 - Government of Ireland, 2002), for instance, it was confirmed that 2002 will be characterized by a GDP growth rate of 'only' $3.5 \%$, and gross national product (GNP) growth rate of 'only' $3 \%$. Moreover, it was suggested that given the recent strengthening of the Euro relative to both Sterling and the Dollar, a tightening labour market giving way to a relatively poor inflation figure of $4.5 \%$, a growing reluctance of the private sector (led by the employers federation IBEC) to enter into a new social partnership agreement, and the particular global problems faced by the Information and Communications Technology (ICT) sector that Ireland is so heavily reliant upon, a resumption of solid growth is by no way guaranteed. Such concerns have in turn resulted (Autumn 2000) in a new wave of fiscal constraints which have been sold by the Irish State as reductions in public sector growth rather than cut backs as such. Whilst some commentators regard this fiscal tightening as little more than early/mid election budget hoarding for a later pre-election fanfare of expansion, it cannot be denied that it heralds a new post-Celtic Tiger phase of economic management.

The impact of this derailment of the country's economic miracle on waste management planning, and in particular the ability of regions to actually carry through and realize the waste management plans remains to be seen. At one level, the reduction in the rapidity of growth might well be conceived of as relieving pressure on the country's already overstretched infrastructure, thereby reducing the urgency with which plans have to be implemented. Such a view would however be misplaced; 10 years of sustained economic growth has meant dramatically higher absolute waste volumes, volumes which demand a radical overhauling of the existing system even in the absence of further growth.

Arguably, the present climate will be exploited to lend further support for the implementation of plans as currently constituted. Ireland's diminishing competitiveness in European FDI and global FDI markets will be used to plead the case that any further burdens on the key export sectors (for instance via increased eco-taxation measures) ought to be avoided. 
Support will be given for options further down the hierarchy which represent cheaper forms of waste disposal for leading capitals. Preserving Ireland's competitiveness, through a depression of production costs and further deregulation of the economy, look set to be the hallmarks of economic management in the near future. To be sure, public funding for capital projects looks set to come under greater scrutiny but this will only lead to greater calls for a heavier input from the private sector in the public-private consortiums that will build Ireland's incinerators and super-dumps. Meanwhile, it remains to be seen whether promised recycling infrastructure will be among the first casualties of the new phase of fiscal retrenchment.

Whatever the outcome, speculation over how waste management planning will be impacted by Ireland's post-Celtic Tiger accumulation strategy serves to drive home the central point advanced in this article: that scale, waste management planning, and national accumulation strategies are dialectically interwoven with one another. The scale division of waste management planning in Ireland is not only rooted in Ireland's accumulation strategy, but as this strategy evolves so too will this scalar hierarchy either be bolstered, revised, or undermined. Of course, any reproduction or transformation of the scalar apparatus will be the subject of a struggle and will be contextual and contingent. Nevertheless, whether Ireland's regional plans will thrive, merely survive, or evaporate in the post-Tiger economy, will shed further light on the power of different constituencies, under particular historical conditions, to shape the scaling of ecological governance. The institutional landscape of waste management planning in Ireland reported earlier represents merely one scripting of an ongoing story, written under a particular but provisional set of power relations which have characterized a regime of accumulation that already looks set to have had its day in the sun.

\section{Acknowledgements}

The author would like to acknowledge the financial assistance received from the Carnegie Trust which facilitated a series of field visits to Ireland whilst conducting this research. Thanks also go to Sharon Galleitch for cartographic assistance.

\section{References}

AlLEN, K. (2000) The Celtic Tiger?: The myth of social partnership in Ireland. Manchester: Manchester University Press.

Baeten, G., Swngedouw, E. and Albrechts, L. (1999) Politics, institutions and regional restructuring processes: from managed growth to planned fragmentation in the reconversion of Belgium's last coal mining region, Regional Studies, 33, pp. 247-258.

BREathnach, P. (1998) Exploring the 'Celtic Tiger' phenomenon: causes and consequences of Ireland's economic miracle, European Urban and Regional Studies, 5, pp. 305-316.

Boyle, M. (2000) Euro-regionalism and struggles over scales of governance: the politics of Ireland's regionalisation approach to Structural Fund allocations 2000-2006, Political Geography, 19, pp. 737769.

Boyle, M. (2002) Cleaning up after the Celtic Tiger: scalar 'fixes' in the political ecology of Tiger economies, Transactions of the Institute of British Geographers, NS 27, pp. 172-194.

BRENNER, N. (1998) Between fixity and motion: accumulation, territorial organisation, and the historical geography of spatial scales, Environment and Planning, D: Society and Space, 16, pp. 459-481.

BRENNER, N. (1999) Globalisation as re-territorialisation: the re-scaling of urban governance in the European Union, Urban Studies, 36, pp. 431-451.

Brenner, N. (2001) The limits to scale? Methodological reflections on scalar structuration, Progress in Human Geography, 25, pp. 591-614. 
Glinch, P., Converey, F. and Walsh, B. (2002) After the Celtic Tiger: Challenges Ahead. Dublin: The O'Brien Press.

Coyle, C. and Sinnott, R. (1992) Regional elites, regional 'powerlessness' and European regional policy in Ireland, Regional Politics and Policy, 2, pp. 71-108.

Cox, K. (1998) Spaces of dependence, spaces of engagement and the politics of scale, or: looking for local politics, Political Geography, 17, pp. 1-23.

DAvoudi, S. (2000) Planning for waste management: changing discourses and institutional relationships, Progress in Planning, 53, pp. 165-216.

Department of Environment and Local Government (1998a) An Overview of the Waste Management Act, 1996. Dublin: Department of Environment and Local Government.

Department of Environment and Local Government (1998b) Waste Management: Changing our Ways. Dublin: Department of Environment and Local Government.

Department of Environment and Local Government (2000) Annual Report, 1999. Dublin: Department of Environment and Local Government.

European Commission (2001) Our Future: Our Choice. Luxembourg: Office for Official Publications of the European Communities.

European Environment Agency (2000) Environment in the European Union at the Tum of the Century. Brussels: European Environment Agency.

Environmental Protection Agency (1999) Proposed National Hazardous Waste Management Plan. Wexford: Environmental Protection Agency.

Environmental Protection Agency (2000a) Ireland's Environment: A Millennium Report. Wexford: Environmental Protection Agency.

Environmental Protection Agency (2000b) National Waste Database Report, 1998. Wexford: Environmental Protection Agency.

Gallego, G. (2002) Waste legislation in the European Union, European Environmental Law Review, 11, pp. 8-15.

Government of IRELAnd (2002) Economic Review and Outlook. Dublin: Stationary Office.

Hooghe, L. (1996) Building a Europe with the regions: the changing role of the European Commission, in L. Hooghe (Ed.) Cohesion Policy and European Integration: Building Multi-level Governance, pp. 89-126. Oxford: Oxford University Press.

LAfFan, B. (1996) Ireland: a region without regions - the odd man out, in L. Hooghe (Ed.) Cohesion Policy and European Integration: Building Multi-level Governance, pp. 320-337. Oxford: Oxford University Press.

M.C. O'Sullivan and Co. Ltd (1999) Draft Waste Management Plan for the Connacht Region. Dublin: M.C. O'Sullivan and Co. Ltd.

MacLeod, G. (1999) Place, politics, and scale dependence: exploring the structuration of Euro-regionalism, European Urban and Regional Studies, 6, pp. 231-253.

MacLeOd, G. and Goodwin, M. (1999) Restructuring an urban and regional political economy: on the state, politics, scale and explanation, Political Geography, 18, pp. 697-730.

MacSharry, R. and White, P. (2000) The Making of the Celtic Tiger: The Inside Story of Ireland's Boom Economy. Dublin: Mercier Press.

Midland Health Board (2000) Public Health and Waste Disposal in Landfill Sites and by Incineration. Tullamore: Midland Health Board.

O'Hearn, D. (1998) Inside the Celtic Tiger: The Irish Economy and the Asian Model. London: Pluto Press.

O'Hearn, D. (2000) Globalisation, 'new tigers', and the end of the developmental state? The case of the Celtic Tiger, Politics and Society, 28, pp. 67-92.

O'Hearn, D. (2001) The Atlantic Economy: Britain, the US and Ireland. Manchester: Manchester University Press.

O'RAIN, S.O. (2000) The flexible developmental state: globalisation, information technology, and the 'Celtic Tiger', Politics and Society, 28, pp. 157-194.

OECD (1999) Environmental Data. Paris: OECD.

OECD (2000) Environmental Performance Reviews; Ireland. Paris: OECD.

OECD (2002) OECD Economic Outlook 71. Paris: OECD.

RudDEN, P.J. (2000) Changing our ways, The Engineers Journal, May.

Smith, N. (1993) Homeless/global: scaling places, in J. Bird, B. Gurtis, T. Putnam, G. Roberston 


\section{European Briefing}

and L. Tickner (Eds) Mapping the Futures, Local Cultures, Global Change, pp. 59-74. Berlin: Springer Verlag.

Swyngedouw, E. (1997) Neither global nor local; 'glocalisation' and the politics of scale, in K. Cox (Ed.) Spaces of Globalisation, pp. 133-166. London: Guilford Press.

Swyngedouw, E. (2000) Authoritarian governance, power, and the politics of re-scaling, Environment and Planning D, 18, pp. 63-76.

Sweeney, P. (1999) The Celtic Tiger: Ireland's Continuing Economic Miracle (2nd edn). Dublin: Oak Tree Press.

TAYLOR, G. (1998) Conserving the Emerald Tiger: the politics of environmental regulation in Ireland, Environmental Politics, 7, pp. 53-74.

The Irish Times (2001a) Ambitious targets set as regions move to solve waste crisis, 10 January, p. 10.

The Irish Times (2001b) Dempsey warns of action on Galway waste, 22 January, p. 12.

The Irish Times (2001c) Waste plan for Connacht rejected by Council, 10 April, p. 8.

Tormans, S. (2001) EG waste law: a complete mess?, Joumal of Environmental Law, 13, pp. 133-156.

Travers, J.J. (2001) Driving the Tiger: Irish Enterprise Spirit. London: Gill and Macmillan.

Turner, R.K., Salmons, R., Powell, J. and Craighill, A. (1998) Green taxes, waste management and political economy, Foumal of Environmental Management, 53, pp. 121-136.

Waste Working Group (2000) Submission on the Draft Waste Management Plan for the Connacht Region. Dublin: Earthwatch.

Wilson, E.J., McDougall, F.R. and Willmore, J. (2001) Euro-trash: searching Europe for a more sustainable approach to waste management, Resources, Conservation and Recycling, 31, pp. 3-20. 